\title{
来島海峡における操船に及ぼす潮流影響に関する研究
}

\author{
小瀬 邦治*・高瀬＼cjkstart悟*・飯島 康弘**
}

\section{Simulation Studies on Current Effects in Kurushima Strait}

\author{
Kuniji KOSE, Satoru TAKASE and Yasuhiro IIJIMA
}

\begin{abstract}
When the ships pass through the Kurushima strait, they are forced to alter the channel in accordance with the direction of the tidal stream. This unique traffic rule often causes the ship's violations of safty at the gateways of strait.

The principal objective of this paper is to generally review this unique traffic rule. As a result of simulation studies of current effects in Kurishima strait, having obtained several valid indication of current effects, when relatively comparing the unique traffic rule in Kurushima Strait with the general maritime traffic rule. We obtained it more difficult to maneuver in the general maritime traffic rule than in that local rule.
\end{abstract}

\section{1. 緒言}

来島海峡は独特の航法である「順中逆西」航法が採用されている。この航法は外国船に馴染みにくいのみ ならず、南流時に抢ける航路出入り口付近での交差、転流時に扝ける行き会いなど衝突を増す可能性を持 っている。このような航法が昭和初期に法令化、あるいはそれ以前に不文律として成立した ${ }^{(1)}$ の、来島海 峡がその狭さと共に強潮流のために交通の難所であることが原因であるが、船船の性能、交通環境は変化 しており、「右側一方通航」施行の可能性も含めて「順中逆西」航法の見直しをする時期であろうと考えられ る。

順中逆西、右側一方通航における潮流・水道・針路の組み合わせは、表 1 に示すように計 6 通りある。 右側一方通行が施行されると、北流時は現在と変わらないが、南流時の組み合わせ 2 つが変化する。この $6 つ$ 組み合わせに対して潮流影響を調查すると、航法の是非を問う検討に資することができる。

本研究では、船が他船の影響を受けることなく、計画航路に沼って航行しようとするとき、潮流が操船 困難度に与える影響を評価することを目的とする。

しかし、来島海峡では強潮流に加え、潮流が著しく不均一であるが、この潮流分布の詳細はあまり計測 されていないうえ、このような潮流下の船の挙動を 表現するモデルも十分に完成しているとは言い難 い。本研究では、現実に計測、推定されている潮流 分布を現在よく使われているMMGモデルをつかっ たシミュレーションに簡単な方法で取り入れ、通陕 時の船の挙動を表すいくつかの指標を見ることで潮 流影響の大枠を把握する。操船困難度を考えるとき、 一元的な指標、あるいはいくつかの指標を一つにま 表 1 潮流・水道・針路の組み合わせ とめた指標によって是非を問いたいところである

\begin{tabular}{|c|c|c|c|c|c|}
\hline \multirow{2}{*}{ 両航法共通 } & \multirow{2}{*}{ 北流 } & 中水道 & 北航 & 順潮 & シナリオ1 \\
\hline & & 西水道 & 南航 & 逆潮 & シナリオ 2 \\
\hline \multirow[t]{2}{*}{ 順中逆西 } & \multirow[t]{2}{*}{ 南流 } & 中水道 & 南航 & 順潮 & シ十リオ3 \\
\hline & & 西水道 & 北航 & 逆潮 & シナリオ4 \\
\hline \multirow[t]{2}{*}{ 右側一方通航 } & \multirow[t]{2}{*}{ 南流 } & 中水道 & 北航 & 逆潮 & シナリオ5 \\
\hline & & 西水道 & 南航 & 順潮 & シナリオ6 \\
\hline
\end{tabular}

*正会員 広島大学（テ739-8527 東広島市鏡山1-4-1）

**正会員 (秼郵船海洋科学（テ140-0004 品川区南品川2-3-6） 
が、本研究はその手がかりになる最も簡単な潮流影響の評価をすることになる。

\section{2. シミュレーションの条件}

\section{1 潮流}

潮流データは海上保安庁水路部によって来島海峡付近の海域全体の時間的場所的分布を与える形で推定 されたすのから、年間で予想される最も強いものをいただいた。この分布は図 $1 \sim 6$ の航跡図に示されて いるが、図中矢印が潮流のベクトルであり、潮流データの位置、大きさ、方向を反映している。これは現 在最も現実に近いデータであるが、マクロな潮流変化を表現しており、洞流のような局地的な潮流変化は 取り入れられていない。

\section{2 潮流の船体運動計算一の反映}

一般に潮流下の船に作用する流体力を表現するために、一般の数学モデルに重心あるいは船体中央位置 における対水速力・加速度を組み合わせる方法が採られる。この方法で潮流変化の緩やかな場合の運動を 推定できるが、潮流に著しい不均一があり、船首尾での潮流差で回頭が誘起されるような場合には適用が 難しい。そこで船首尾方向に抢ける潮流の不均一の影響は対水の角速度・角加速度の形で考慮することに した。

\section{3 制御則}

シミュレーションを実施するには操船者の制御モデルが必要になる。操船者はまず方位を維持し、必要 に応じて計画航路からの船位ずれを修正するため、舵角をとると考えられる。そこで、指定された方位を 保持する比例・微分制御と、計画航路からのずれを修正するため、計画航路上船長の 2 倍先を向首させる という位置制御を導入した。簡単だが実際に近いモデルと考えている。制御定数は通狭がうまくいくよう に調整し、シナリオ毎の比較ができるよう今回示したシミュレーション例では統一している。著しく制御 能力を損なう制御定数にしない限り、今回得た結論には影響しない。

そのほか、実際にシミュレーションを実施するには、計画航路を与える必要があり、実務経験者に設計 をお願いした。現航法に存在しない右側一方通における南流時の計画航路は、北流時のものを用いた。航 船は船長による違いを見るために $75 \mathrm{~m}$ の小型船、 $200 \mathrm{~m}$ の大型船を用い、主機回転数は最近の平均船速が 10〜15knotであることから ${ }^{(2)}$ 対水速度 $12 \mathrm{knot}$ の回転数とした。

\section{3. 評価指標の選出}

船の挙動における潮流影響を表しうる指標として以下の 4 つを取り上げた。

一つに、制御結果の良さを表す指標として、計画航路からの距離、すなわち偏位を選んだ。ここでの偏 位の定義は計画航路と船体重心の距離である。これは乗り上げや、衝突に直接関係する。

続いて、通峡する際に船にかかる負担を表現する指標として舵角を取り上げた。舵角は、平水中といえ ども変針に必要な舵角と、潮流によって生じた偏位を修正するための舵角に分離する、という方法も考え られるが、変針を難しくする潮流というものが危険であるという観点から、シミュレーション結果から得 られるそのままの舵角を性能上の負担として取り上げた。

また、船体が斜航すると操船者はそれを考慮して船首方位を選ぶ必要があり、この斜航角が10～15(deg) を超えると船位保持が著しく困難になると言われている。そこで、斜航角を操船困難度を表す指標として 取り上げた。

最後に、本研究の目的である潮流影響の程度を評価するために、時々刻々の船体横方向の潮流速も指標 とした。同じ潮流分布を与えていても、通過する位置や方位で受ける潮流影響は違うことになるから、こ の指標は現実に受ける潮流影響の目安となる。著しい潮流不均一がある場合、船首尾における潮流差を指 標として加えることも考えられるが、今回は潮流分布が緩やかであるから、指標にはしなかった。

\section{4. シミュレーション結果}




\section{1 指標間の相関}

前節で示した指標と同様な指標の選出、及びシミュレーションによる来島海狭への適用は既に小林らに よって報告されている( ${ }^{(3)(4)}$ 。小林らは一様潮流下の変針における指標の時間平均から、唯一の指標で評価す ることが妥当でないことを示し、複数の指標の重ね合わせにより $\mathrm{E}$ 值、 $\mathrm{E} *$ 值を定義し、来島海陕の操船困難 度を評価している。本論では潮流が場所的に不均一であることを考慮し、それぞれの指標の来島海峡にお けるタイムヒストリから考察を進めていく。

シミュレーション結果の例として、大型船の航跡図と指標のタイムヒストリを図 $1 \sim 6$ に示す。

航跡図において点線が計画航路であり、30秒每の航跡を船型によって示している。航跡図と指標のタイ ムヒストリの対応を見やすくするために、航路中央付近で、航跡図における計画航路に対して横線を引き、 該当する時間を指標のタイムヒストリにおいて示した。指標のタイムヒストリは4.2節で述べるようにおよ そ限界と考えられる値を 1 として正規化してある。

順潮時において変針の際オーバーランしてしまう様子や、逆潮時において変針を妨げる向きに船体横方 向の潮流が強い場合、変針が困難になっている様子など、実際の操船局面において現れる現象と一致して おり、このシミュレーションの妥当性が示されている。

指標のタイムヒストリより、どのシナリオに掠いても変針点付近で舵角が大きくなっているものの、全 体を通して指標間に相関がある事が見て取れる。

小型船のシミュレーション結果は省くが、通峡における指標の変化の傾向、指標間の相関は大型船と同 様であった。

\section{2 指標の正規化}

ここで各指標における許容限界について考える。

船が外力によって横方向に流される時、操船者はそれをキャンセルするように船首方位を調整する。こ の横漂流を検出するには固定物標からの測位に頼ることになり、実際に時々刻々の斜航状態を推定するの は容易ではない。つまり、実際の操船者は通峡中、地形や交通環境も考慮して時々刻々妥当な許容限界を 設计ていると考えられる。しかし、本研究では船の挙動に与える潮流影響を通峡全般にわたり同等に評価 する目的であるから、10(deg)を超えるような斜航をすると、それに対応する方位をとるのが困難になると 言われている事に着目した。その限界は定かではないが、およそ10 (deg)～15(deg)くらいと言われること

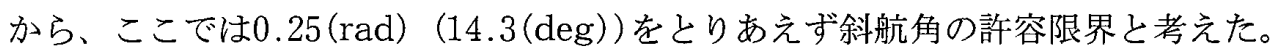

これに対応する偏位は $2 L \times 0.25 て ゙ 0.5 L$ なる。これは $2 L$ 先を目標とする今回の制御則から説明され る。

同様に船体横方向の潮流速は前進速度の0.25倍と近似できる。ここでは簡単のため期待される対水前進 速度 (12(knot))の0.25倍とした。

舵角は物理的に限界である35(deg)をとりあえず許容限界とした。

\section{3 指標の平均の相関}

ここで潮流影響のシナリオ毎の違いの大枠を見るために、シナリオ毎に各指標を航路にわたって平均し た結果を図 7 に示す。航路は航行制限区域内の、今回の潮流データの流速が $3 \mathrm{knot}$ 以上の範囲を中心とし た範囲を対象した。指標は前述したような許容限界で正規化してある。

全体として大型船のほうが指標值がやや大きいものの、大型船・小型船ともにシナリオによる指標の違 いが、各指標似ていることが見て取れる。シナリオ毎の指標の平均の相関を図 8 に示す。指標間は強い相 関を示している。

このことは、指標の平均でシナリオを相対的に比較する場合、指標間で矛盾が起きにくい事を示してい る。よって、今回船の挙動にお污る潮流影響の評価指標として取り上げた $4 つ$ 指標は何れも、相対比較 においては、困難度の平均とみなしてよいと考光られる。

そこで、各シナリオを比較してみた。

\section{5 シナリオの比較}

4.4.1順潮・逆潮による指標の平均の違い

同じ水道における順潮、逆潮によるシナリ才毎の指標の平均の違いを表 2 に示す。特に、右側一方通航 が施行された場合、現航法の北流時と同じ水道、同じ針路で南流時に通峡する状況ができることから、北 


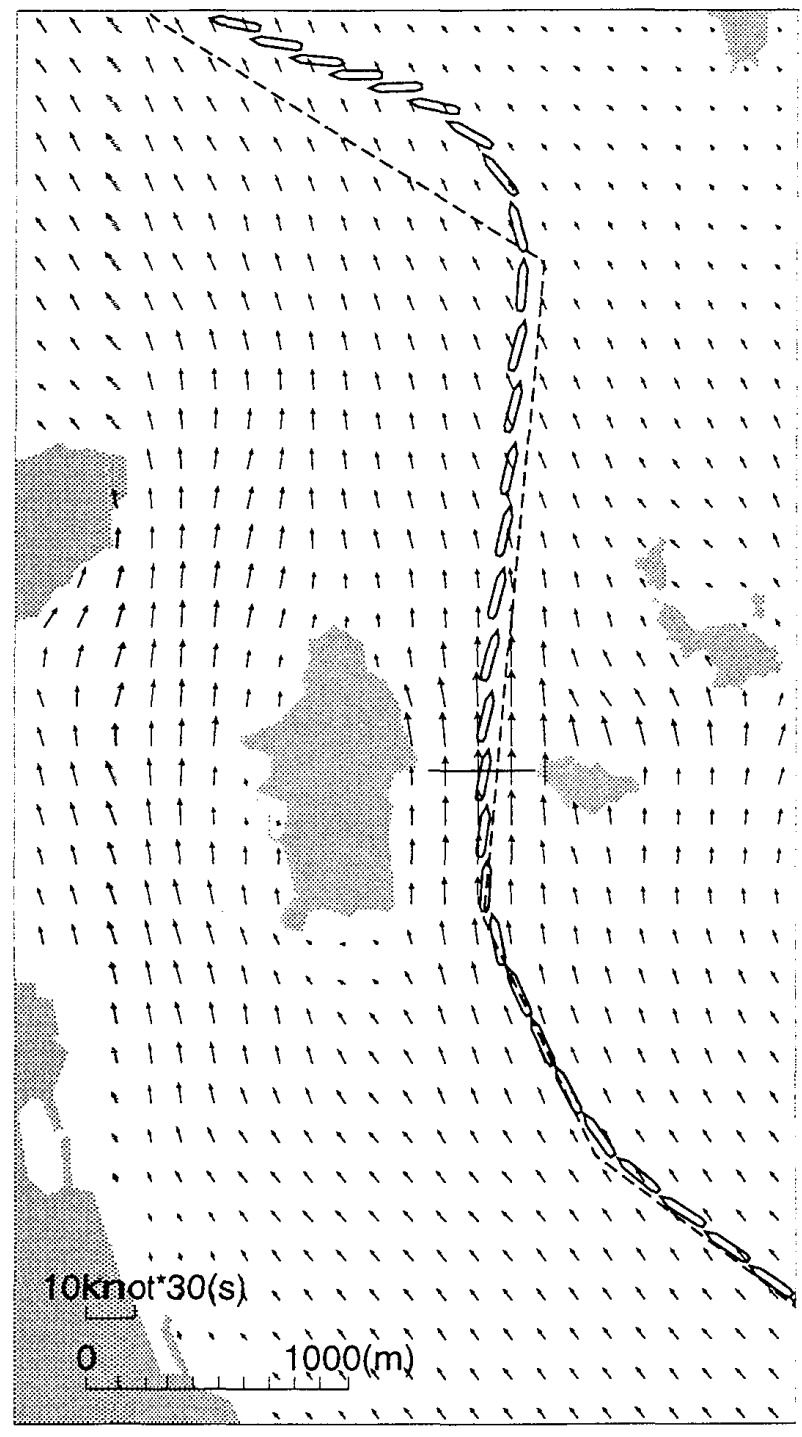

(a) 航跡図

北流・中水道・北航（シナリオ1）

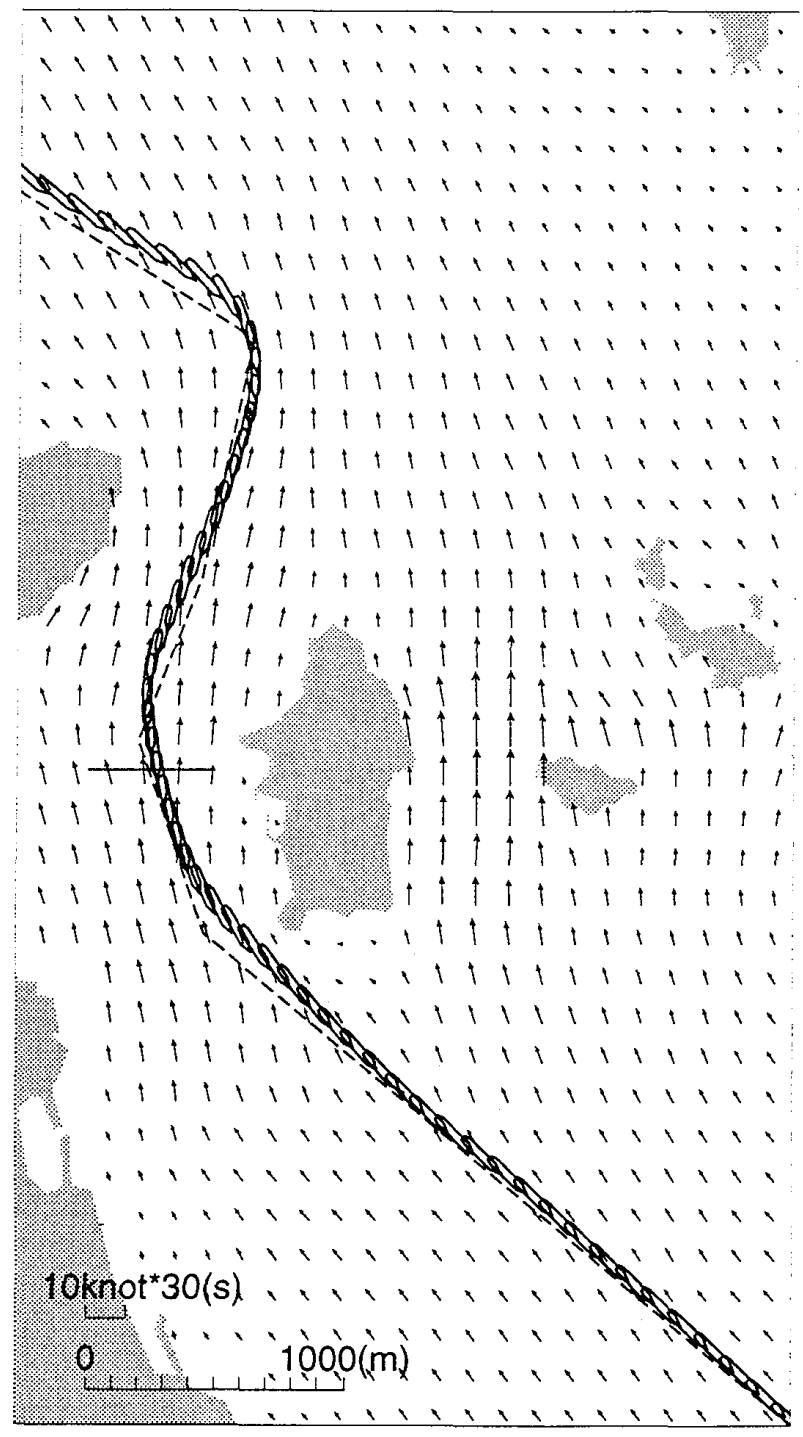

(a) 航跡図

北流・西水道・南航（シナリオ 2 ）

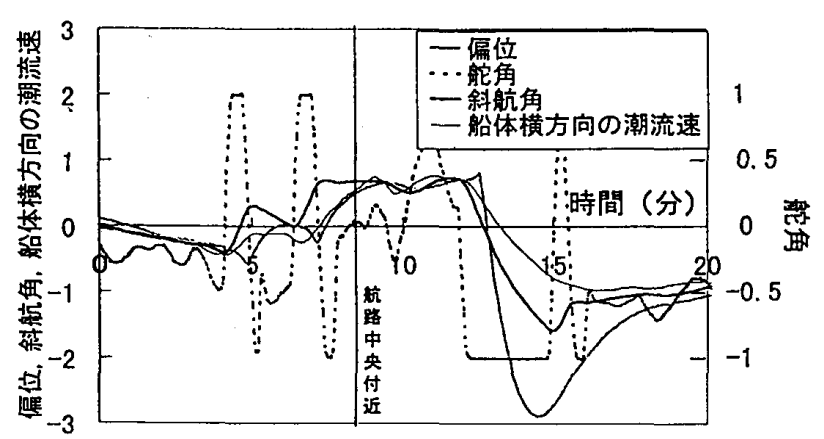

（b）指標のタイムヒストリ 北流・中水道・北航（シナリオ 1 )

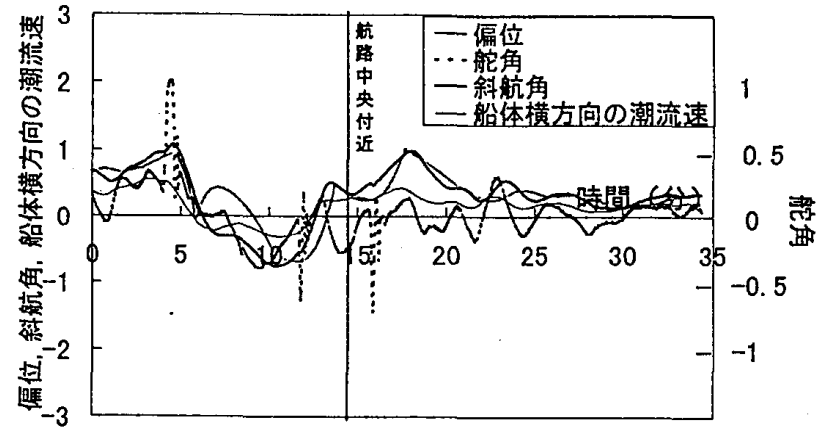

（b）指標のタイムヒストリ 北流・西水道・南航（シナリオ 2 ） 


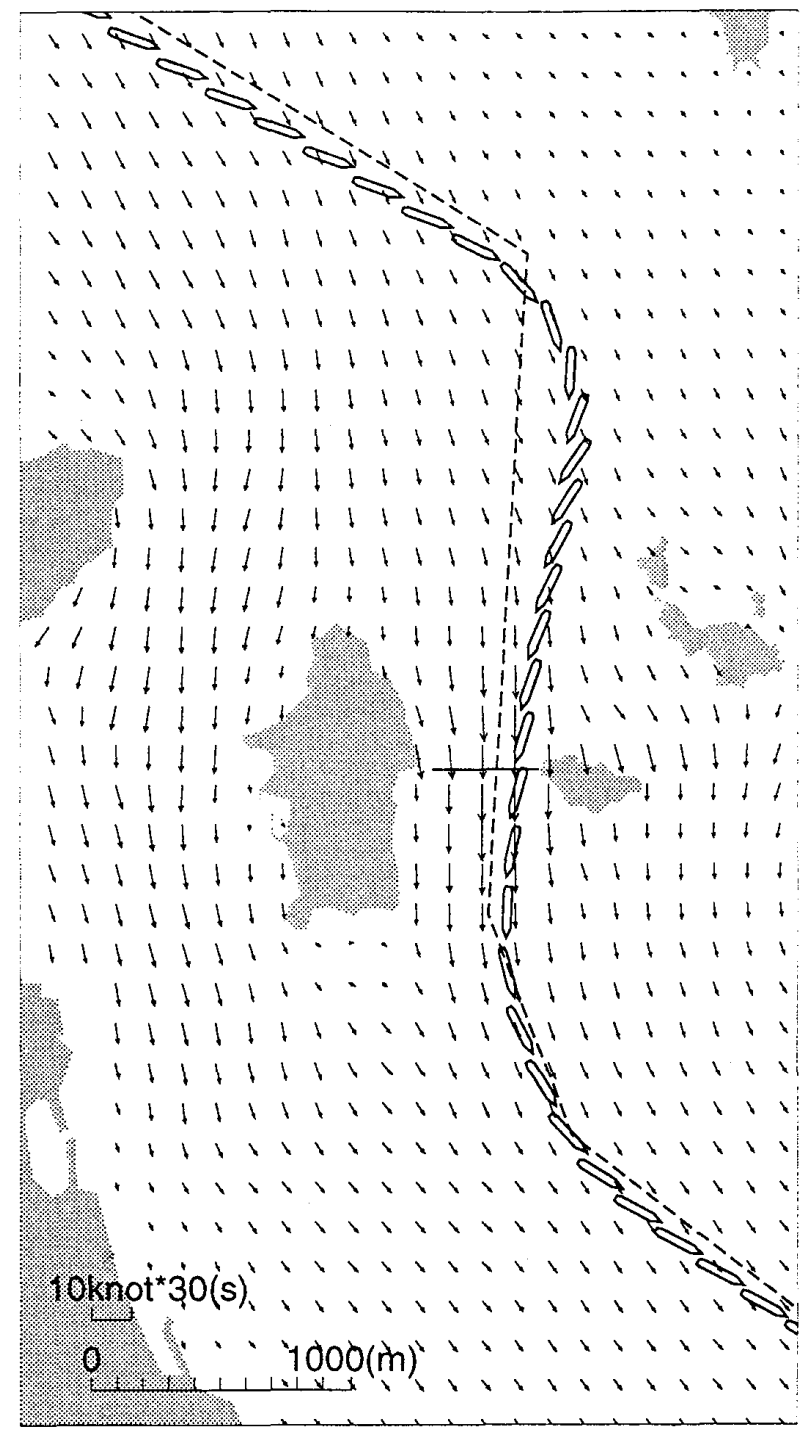

（a）航跡図

南流・中水道・南航（シナリオ 3 )

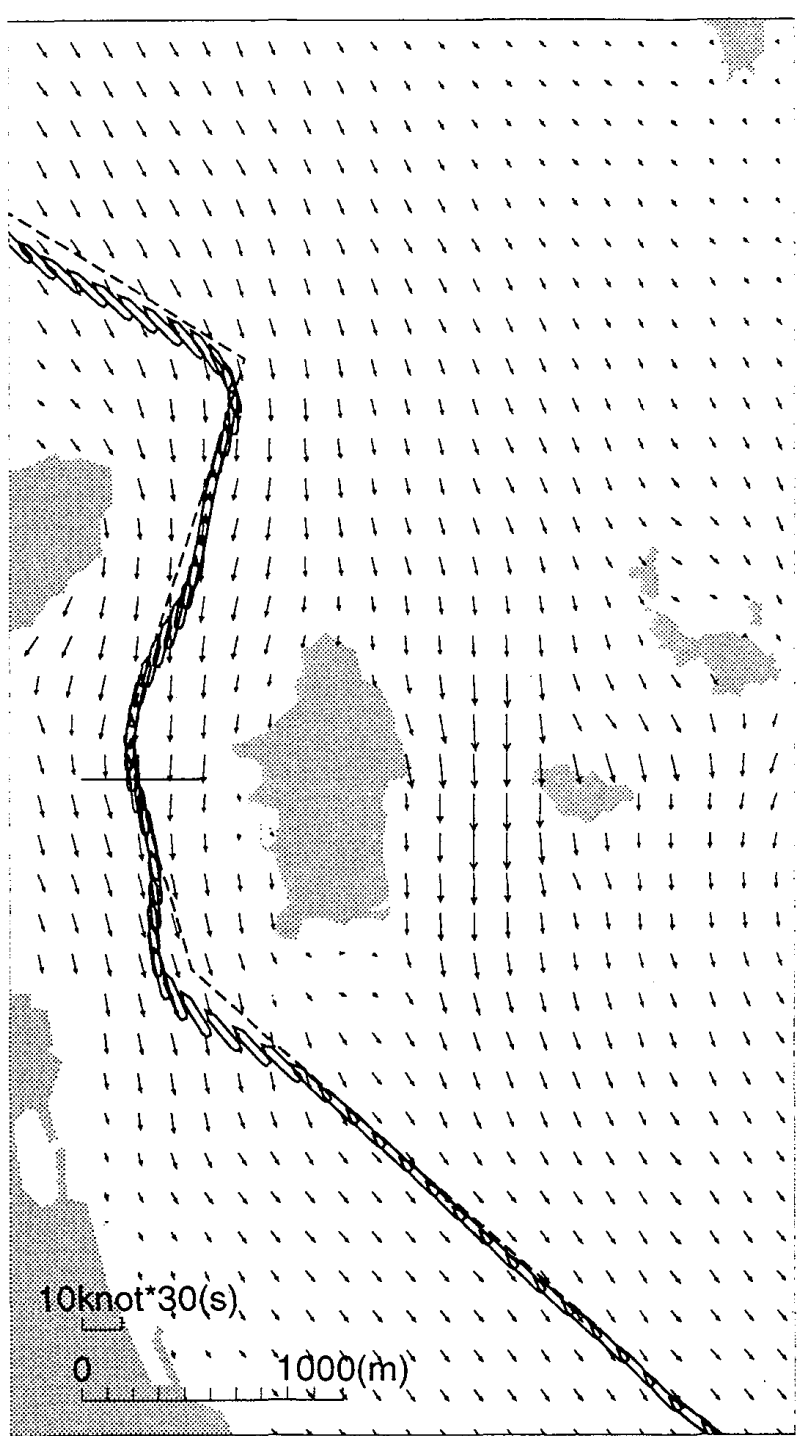

（a）航跡図

南流・西水道・北航（シナリオ4)

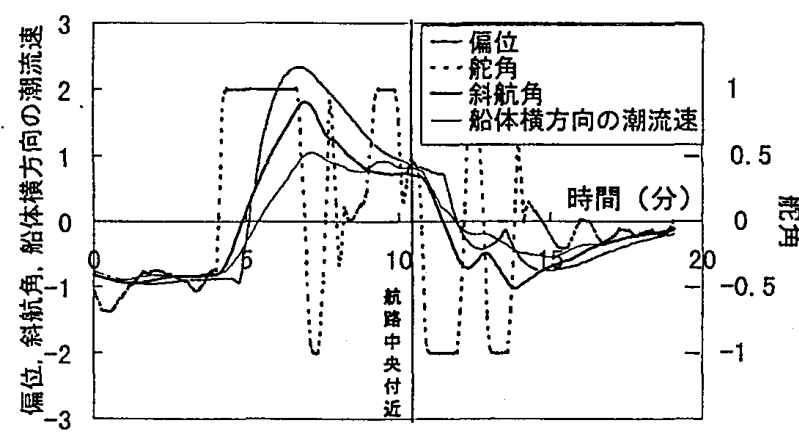

（b）指標のタイムヒストリ 南流・中水道・南航（シナリオ 3 ）

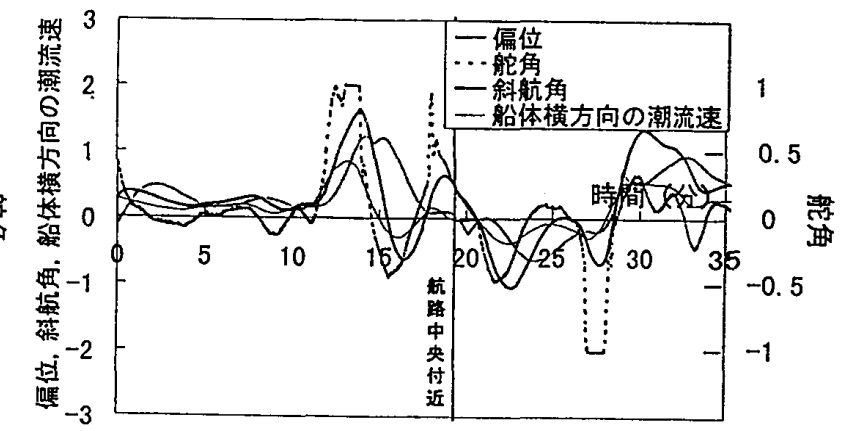

（b）指標のタイムヒストリ 南流・西水道・北航（シナリオ 4) 


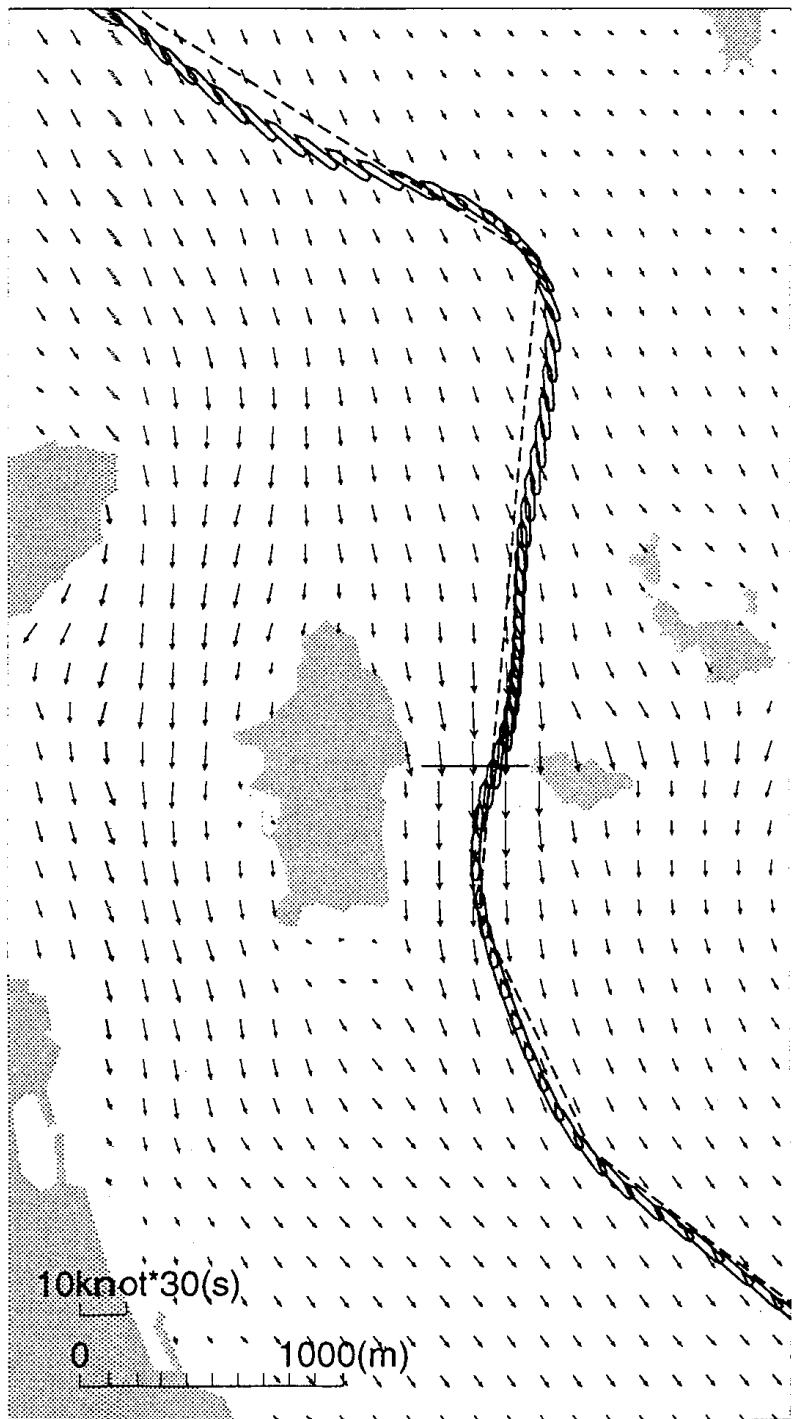

（a）航跡図

南流・中水道・北航（シナリオ 5 )

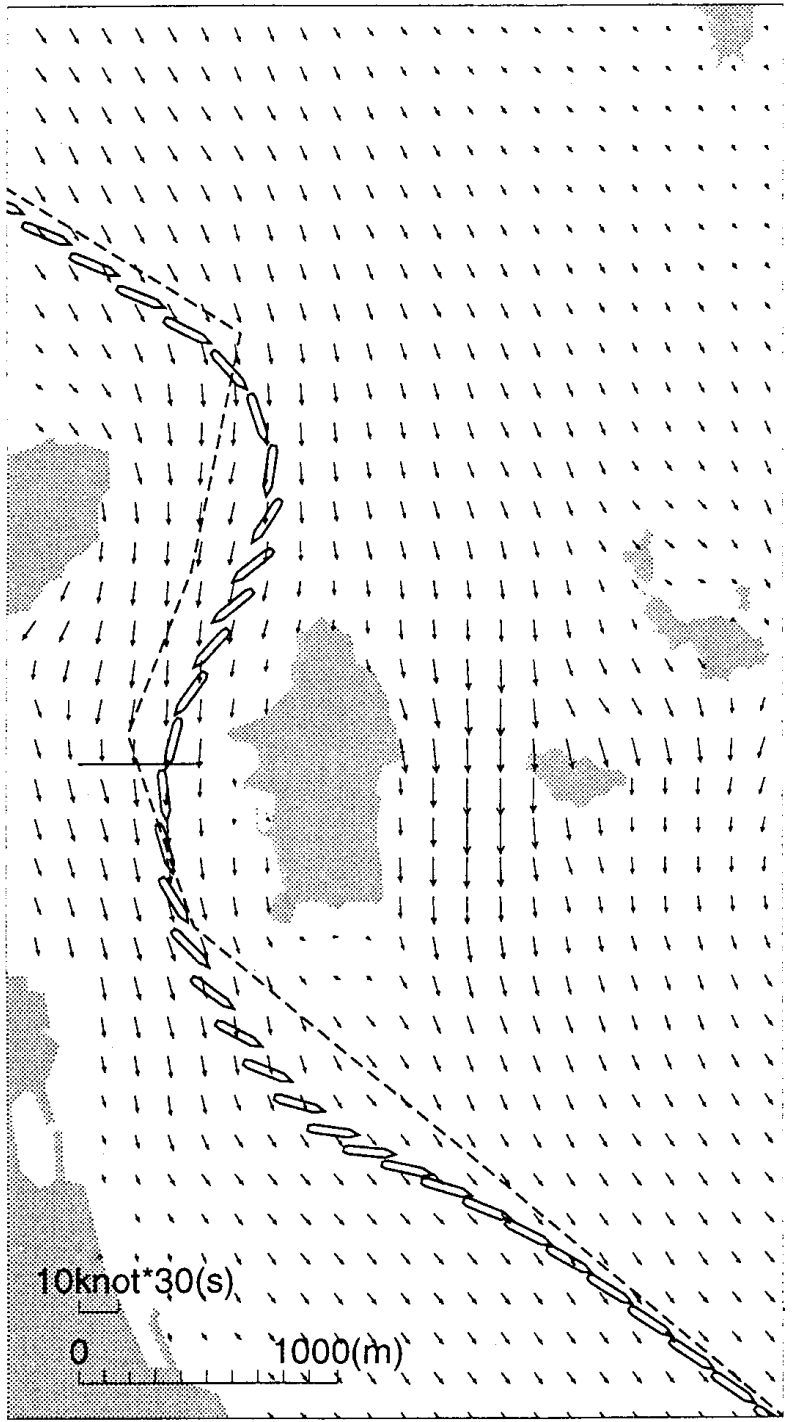

(a) 航跡図

南流・西水道・南航（シナリオ6)

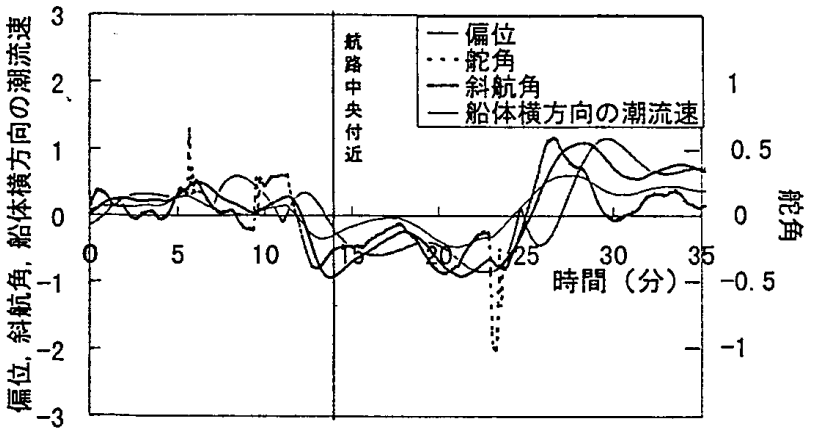

（b）指標のタイムヒストリ

南流・中水道・北航（シナリオ 5 )

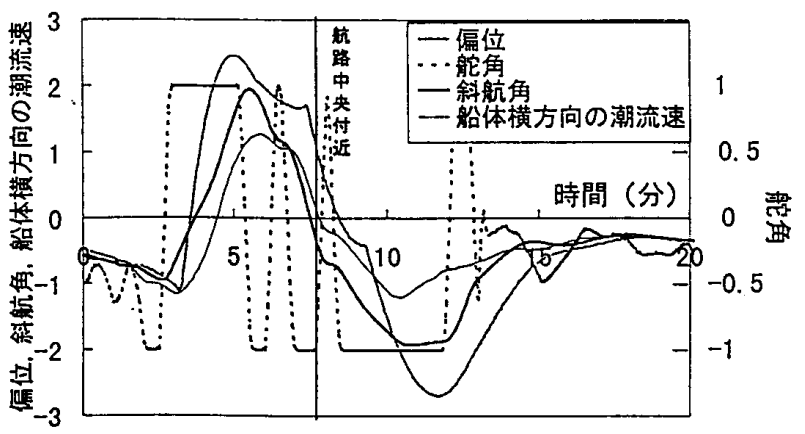

（b）指標のタイムヒストリ 南流・西水道・南航（シナリオ 6 ) 


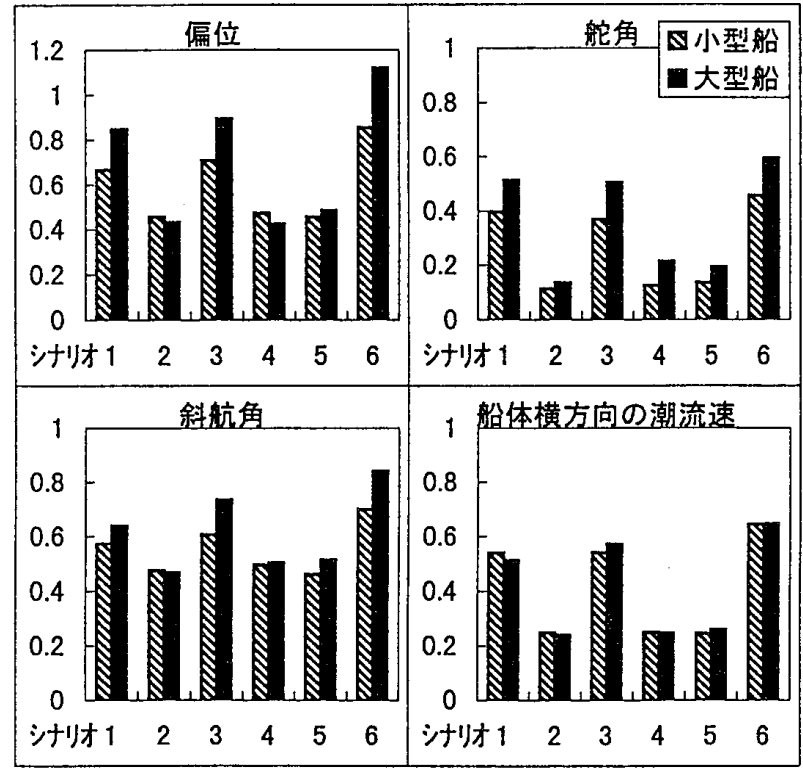

図 7 シナリオ毎の指標の平均

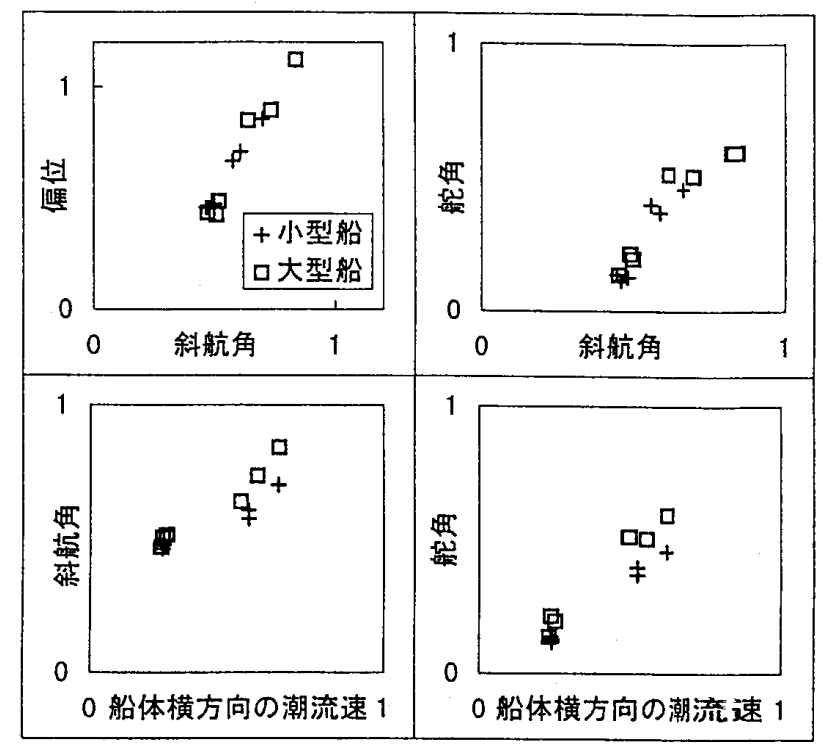

図 8 指標の平均の相関

表 2 順潮・逆潮による指標の平均の違い

\begin{tabular}{|c|c|c|c|c|c|c|c|c|}
\hline \multicolumn{3}{|c|}{ 中水道 } & \multicolumn{3}{|c|}{ 水道 } & \multicolumn{3}{|c|}{ 西水分直 } \\
\hline 北航 & 南航 & 北航 & & 針路 & & 南航 & 北航 & 南航 \\
\hline 順潮 & 順潮 & 逆潮 & & 潮向 & & 逆潮 & 逆潮 & 順潮 \\
\hline 1 & 3 & 5 & & シナリオ & & 2 & 4 & 6 \\
\hline 1.0 & 1.1 & 0.7 & 小型船 & 偏位 & 小型船 & 1.0 & 1.0 & 1.9 \\
\hline 1.0 & 1.1 & 0.6 & 大型船 & & 大型船 & 1.0 & 1.0 & \\
\hline 1.0 & 0.9 & 0.3 & 小型船 & 舵角 & 小型船 & 1.0 & 1.1 & \\
\hline 1.0 & 1.0 & 0.4 & 大型船 & & 大型船 & 1.0 & 1.6 & \\
\hline 1.0 & 1.1 & 0.8 & 小型船 & 斜航角 & 小型船 & 1.0 & 1.0 & 1.5 \\
\hline 1.0 & 1.2 & 0.8 & 大型船 & & 大型船 & 1.0 & 1.1 & 1.8 \\
\hline 1.0 & 1.0 & 0.5 & 小型船 & 船体横方向 & 小型船 & 1.0 & 1.0 & \\
\hline 1.0 & 1.1 & 0.5 & 大型船 & の潮流速 & 大型船 & 1.0 & 1.0 & \\
\hline
\end{tabular}

基準

基準

表 3 水道による指標の平均の違い

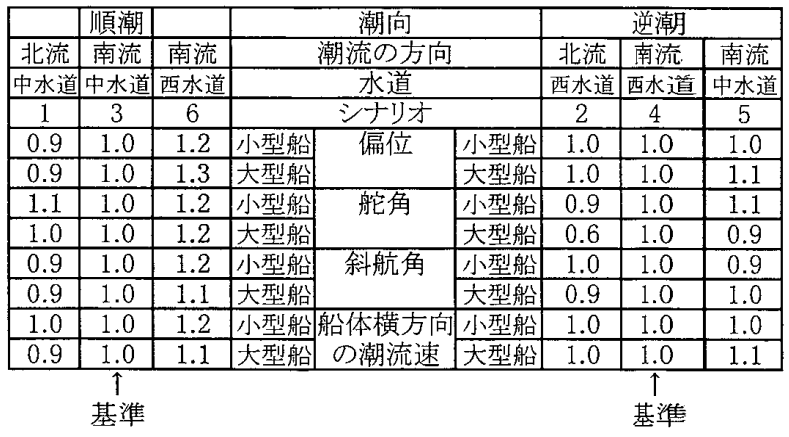
間の制御の簡単なモデルを導入してシミュレーション を実施し、検討した。この結果得られた結論は次のよ うに要約できる。

今回選んだ指標の平均は、相対比較において有効であり、比較の結果、南流時・西水道を南航する場合 (シナリオ 6 )の困難度が大きいことが定量的に検証できた。今後その困難度がでの程度で、許容できる範 囲か否かの検討が必要であると指摘できる。

本研究では、許容限界を操船困難とされている斜航角を基に策定したが、このような許容限界の問題は、 実船実験や操船シミュレータ実験ともリンクして、今後検討を重ねなければならない。

この研究は日本海難防止協会による「輻輳海域に扮ける海上交通安全制度についての調查研究」の一環と 
して行われた。日本海難防止協会、海上保安庁水路部の皆様をはじめ関係者の皆様に深く感謝致します。 また、多くの議論をくださった広野康平氏に感謝いたします。

\section{参 考 文 献}

（1）多田光男：来島海峡の通航方法についての史的考察，日本航海学会誌，122号，1994.

（2）日本海難防止協会：平成 7 年度輻輳海域における海上交通安全制度についての調查研究中間報告書, 1996.

（3）小林弘明・田中清隆：外乱下における変針制御について，日本航海学会論文集，86号，1991.

（4）小林弘明・田中清隆：外乱下における変針操船の困難度についてーII, 日本航海学会論文集，87号， 1992.

\section{質 疑 応 答}

林 美鶴(神戸商船大学)：潮流のグリッドの間隔、シミュレーションを行った船の大きさは何mですか。 また、船体各点における潮流の計算方法はどのようにしましたか。

飯島康弘：潮流データは $128 \mathrm{~m} \times 154 \mathrm{~m}$ で、船体の大きさは $75 \mathrm{~m}$ と $200 \mathrm{~m}$ を心にシミュレーションを行いま した。船体各点の潮流は、その周りの潮流を比例配分することで補間計算し、船体まわりでの不均一な 潮流を表現いたしました。今回は潮流のマクロな流れによる潮流影響を前提として指標を選出、解釈致 しましたので、この計算方法で妥当と考えます。

大津皓平(東京商船大学)：制御則において、dを入れるよりI制御を入れた方が良いのではないでしょうか。 飯島康弘：制御則が変わればシミュレーション結果は変わるのですが、潮流影響に関する解釈は同じでな ければなりません。そのため、操船者の操船を模擬しつつも、解积のしやすい簡単な制御を用いました。 ご質問の趣旨が位置誤差に対する積分制御の効果と理解しますと、制御系の安定性を含めて検討する必 要があり、船や水道の大きさ等を考慮に総合的に判断する必要があると考えます。

芳村康男(住友重機械工業)：針路安定船と不安定船の違いはどうなりますか。

飯島康弘：潮流下における位置制御の安定性は低く、許容限界などを踏まえて絶対的に評価する際、操縦 性能が重要なパラメータになると考えられます。今回は相対比較まででしたので、供試船として従来か ら運動性能研究によく用いられるESSO OSAKAを基にしたデータを用いました。 